\title{
A magyar Fokker D.VII-es vadászrepülőgépek története
}

A magyar katonai repülés egyik meghatározó típusa az I. világháború végének legjobb vadászgépe, a Fokker D.VIl-es volt [1]. Kisebb-nagyobb mennyiségben, aránylag hosszú ideig (1918-1935) alkalmazták Magyarországon, csővázas szerkezete pedig mintául szolgált több magyar tervezésű repülőgépnek. $A$ források hiánya miatt e gépekről néhány téves információ is bekerült a köztudatba, de a napjainkban végzett kutatások pontosítják a magyar D.VII-esek történetét.

A világháború végén a magyarok 3 féle módon jutottak hozzá a Fokkerekhez: részben vásároltak Anthony Fokker schwerini gyárából félkész gépeket, a balkáni német hadseregtől lefoglaltak példányokat, de a Magyar Általános Gépgyár (MẢG) mátyásföldi telephelyén licenc alapján gyártottak is ilyen típusú gépeket.

Az 1918 január-februárjában lebonyolított német vadászgéptendert megnyerő V.11/D.VII-es [14, 17, 22] után az Osztrák-Magyar Monarchia is érdeklődött, ezért a monar-

1. ábra. A 8. vörös repülőszázad megalakulása. Bal oldalon a két német eredetű és német álcázófestésű Fokker $D$. VII-es, Magyarországon gyártott motorral (Winkler Aero Archív)

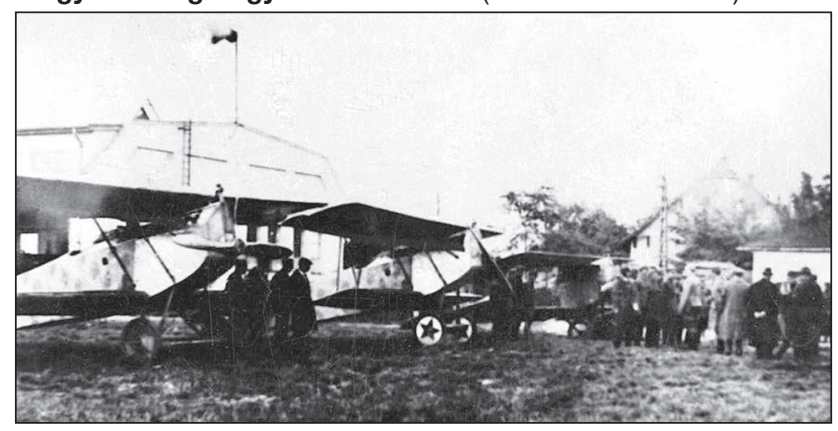

ÖSSZEFOGLALÁS: Az első világháború végén, a német tervezésű Fokker $D$. VII-es vadászgép korának egyik legjobb vadászrepülőgépe volt. A nagy háborút követően még mintegy tucatnyi ország légiereje tovább üzemeltette különböző változatait, és gép aktív részese volt a háborút követő konfliktusoknak is. A D.VII-esek építése Magyarországon is elkezdődött (a mátyásföldi telephelyen 1918 második felében kezdték meg a gyártását), de a központi hatalmak októberi veresége és az Osztrák-Magyar Monarchia felbomlása miatt a gyárat kénytelenek voltak leállítani. A már leszállított, gyártásba vett és rekvirált kész, félkész, sérült példányokat az újonnan kikiáltott köztársaság, később a Tanácsköztársaság és a Nemzeti Hadsereg is használta hazánkban. A cikk a Magyarországon repült Fokker D. VII-esek alkalmazásának történetét ismerteti, eddig csak szűk szakmai körben publikált dokumentumok és források alapján.

KULCSSZAVAK: I. világháború, Fokker D. VII, acélcsőrács-szerkezetű törzs, Magyar Általános Gépgyár, Lloyd Repülőgépgyár, Anthony Fokker, AustroDaimler motor, Hiero motor, Sóstó, Gebauer motorhajtású géppuska

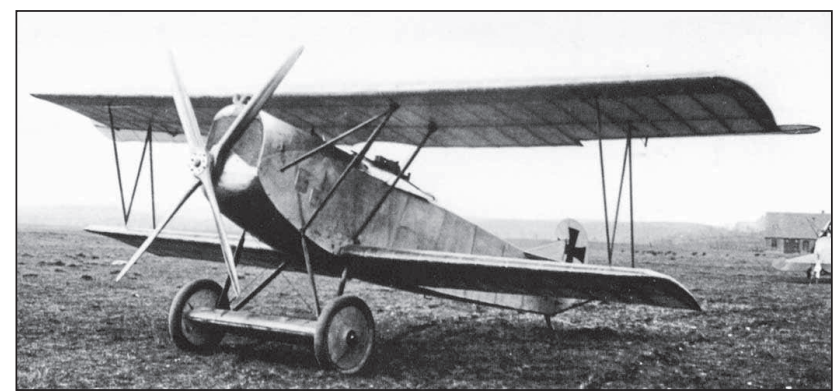

2. ábra. A Monarchia kívánalmai alapján épített V.22/D.VII-es a schwerini repülőtéren. Jól látható, hogy a gép oldalkormányát egy másik repülőről szerelték át, ebben az esetben a V.21-esröl, ami a németek számára épített harmadik D.VII-es prototípus volt (Fotó: airwar.ru)

chia kívánalmai alapján a Fokker repülőgépgyárban megépítették a V.22 jelű (2342 gyári sz.) prototípust [17, 31]. Az egyik igény egy nagyobb kapacitású, de hazai gyártású motor alkalmazása volt, amit ebben az esetben egy 210 LE (155 kW) teljesítményű Austro-Daimler típussal oldottak meg (19245 gyári sz). A másik követelmény - nyilván a saját fegyvergyártás élénkítése érdekében - a gép osztrák-magyar Schwarzlose géppuskákkal (34511 és 34537 gyári sz.) történő felszerelése volt, pedig ezeknek kisebb volt a tűzgyorsasága a németek által használt Spandau géppuskáknál [31]. A repülő építését még február elején elkezdték, március első hetében már fel is szállt $[16,31]$. Ekkor a géppuskaszinkronizáció miatt négyágú csúsztatott „X” (60\%120ª́llású) Jaray-légcsavarral repült.

A repülőt, 1918. április 24-én maga a konstruktőr, Anthony Fokker hozta el a MÁG mátyásföldi repülőterére bemutatni $[17,31]$. Ez a példány már kétágú légcsavarral és

ABSTRACT: At the end of World War I, the German-designed Fokker D. VII fighter was one of the best fighter jets of its age. After the Great War, the air forces of about a dozen more countries continued to operate various versions, and aircraft were also active participants in the post-war conflicts. Building the D. VIls also began in Hungary (production began at the Mátyásföld site in the second half of 1918), but the factory was forced to shut down due to the defeat of the central powers in October and the collapse of the Austro-Hungarian Monarchy. The finished, semi-finished, damaged specimens that had already been delivered, taken into production and requisitioned were also used in Hungary by the newly proclaimed republic, later by the Soviet Republic and the counter-revolutionary troops. The article describes the history of the employment of Fokker D. VIls that flew in Hungary, based on documents and sources published only in a narrow professional circle.

KEY WORDS: World War I, Fokker D. VII, steel-tube fuselage, Hungarian General Machine Factory, Hungarian Lloyd Aircraft and Motor Works, Incorporated, Anthony Fokker, Austro-Daimler engine, Hiero engine, Sóstó, Gebauer motor-driven machine gun 


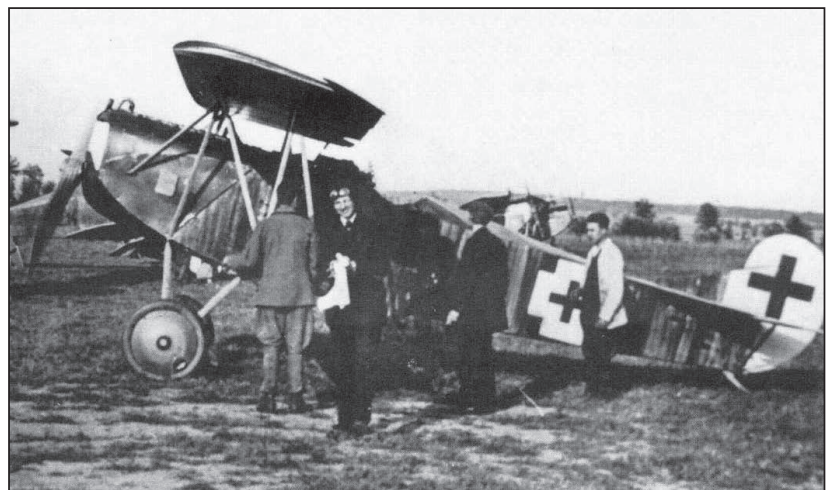

3. ábra. A V.22-es a korai D.VII-esek (zöld csíkos) festésével a Mátyásföldi repülőtéren, a Flars-nak tartott bemutatón.

Előtérben a holland Anthony Fokker (Fotó: airwar.ru)

a korai D.VII-esek zöld csíkos festésével tartott bemutatót $[3,31]$. A Fliegerarsenal (Flars) vezetésének elnyerte tetszését, a mintapéldányt további repülési próbákra a fischamendi katonai repülőtérre szállították. A gép a 90.05 monarchia lajstromszámot kapta [12], ahol a 9-es a MÁGot, a 0 pedig a kísérleti repülőt jelezte. Hosszas repülési próbák és tárgyalások után, 1918 októberétől a Fokker D.VII-est választották az Aviatik D.I és Albatros D.III vadászgépek leváltására. A program augusztustól lépett életbe, összesen 660 db Fokker legyártását irányozta elő, ebből 150 db jutott a MÁG-nak [6, 12]. Mivel az acélcsőrácsszerkezetű törzs építése ekkoriban még nagy technikai kihívásnak számított, ezért a MÁG-ot kivéve, az összes üzem visszamondta a gyártást. A Flars ezért egy technológiailag egyszerübb, csak faszerkezetű Austro-Daimler motoros D.VII „Holzrumpf-ot” is rendelt Anthony Fokkertől, amit le is szállítottak augusztus 27-én a bécsi (asperni) Arzenálba $[19,31]$. A Holzrumpf azonban a tiszta faszerkezet miatt nehezebb és lomhább volt. Ennek áthidalására a Flars augusztusban szerződést kötött a Fokker céggel további 75 db Fokker D.VII vadászgép leszállítására, motor és fegyverzet nélkül. Ezeket is a MÁG repülőgépgyára kapta meg végső összeszerelésre. Miközben a központi hatalmak frontjai sorra összeomlottak, addig 1918. október 29-én még megérkezett szállító állványon Mátyásföldre az első 6 db motor nélküli, szétszerelt Fokker D.VII-es repülősárkány, az alábbi gyári azonosító számokkal: 3861, 3863-3867-ig [6, 31]. A két prototípus darabjáért 30 000, a motor nélküli széria gépekért egyenként 23500 német márkát számolt fel Fokker [31].

\section{D.VII-ESEK A BALKÁNON}

A három balkáni német közelfelderítő repülőszázadot $(30$, 34 FA ill. 246 FAA) két német vadászszázad támogatta a háború végén: a Jasta 25 és a Jasta 38 [11, 17]. A Fokker D.VII-es korszak 1918. július elején kezdődött a makedón arcvonalon lévő vadászoknál, ekkor kapott mind a két Jasta (Jagdstaffel) repülőszázad 1-1 D.VII-es korai gyártású vadászgépet. Gerhard Fieseler gépe különösen híres lett, mert felül mindig az évszaknak megfelelő mintázatra, alul égszínkékre festette. Egy zsákmányolt Lewis géppuskát erősített a felső szárnyra $45^{\circ}$-ban, és földközelben repülve alulról lőtte le az antant repülőgépeit. Ez a plusz géppuskás Fokker előfutára lett a II. világháborús német éjszakai vadászrepülőkön alkalmazott fegyver-elhelyezési módnak, az ún. „Schräge Musik”-nak, amely segítségével a gépágyúkkal hátrafelé-fölfelé irányban lehetett lőni [17].

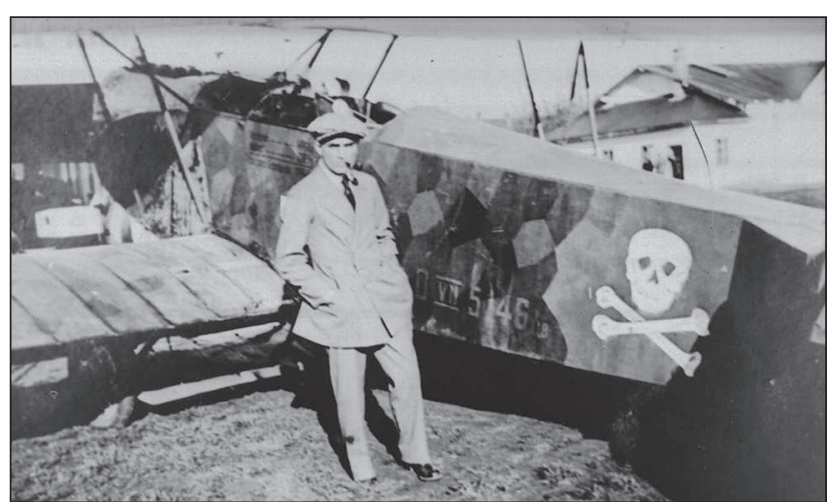

4. ábra. Kaszala Károly 9 győzelmes repülőász a zsákmányolt 5146/18 Mercedes motoros D.VII-esel. A lefoglalt német repülök többsége nagyon elhasznált volt (Winkler Aero Archív [11])

Mivel a Balkánon az ellenség nyomasztó túlerőben volt, kerülték a rikító színeket a gépeiken, a visszaemlékezők szerint több repülőgép is tereptarka mintázatot kapott [31]. A szeptemberi antant támadás során a balkáni front összeomlott, napokon belül Bulgária kivált a háborúból. A német csapatok tovább hátráltak északra, de a november 3-i olasz fegyverszünettel a Monarchia is felbomlott. A november 13-án aláirt fegyverszüneti egyezmény amellett, hogy jelentős nagyságú Magyarországhoz tartozó terület megszállását és csaknem teljes katonai leszerelést írt elő, a Mackensen-hadseregnek a Balkánról való, 15 napon belüli kivonásáról, valamint az országon átvonuló német csapatok lefegyverzéséről és internálásáról is rendelkezett $[16,19]$. December 7-én felálltak a lefegyverző bizottságok, de addigra a német katonák egy része már magától hazaindult. A repülők zárt vagonokban álltak a síneken, jelentős részüket Jászapátiban foglalták le. A cinkotai repülőanyagszertárba beszállított német $\mathrm{D}$.VII-es példányok jelölése, állapotuk szerint csoportosítva [11, 17, 25]:

- erősen sérült, de javítható 322/18, 598/18, 4053/18, 4067/18, 5061/18;

- gyengén sérült (pl. szakadt vászon) 5141/18, 5207/18,5209, 5287/18, 5319/18, 5323/18, 5328/18, $5329 / 18,7606 / 18$.

A kis darabszám ellenére, elég vegyes gépállomány jött össze, például a 322/18-as standard 160 LE-s (118kWos) Mercedes D.Illa motoros korai Fokker gyártású, de többségük az erősebb 180 LE-s (132 kW-os) Mercedes Illaü motorral volt felszerelve. Ez utóbbiak közül minden Fokker-gyárból voltak példányok, például a 4053/18-as OAW, az 5141/18-as Fokker, valamint az 5328/18-as Albatros [4, 11, 17, 31]. (Fokker schwerini üzeme kis kapacitású volt, ezért szállt be a gyártásba a két nagy német

5. ábra. Az első MÁG építésū D.VII-es, a 93.01-es váza. Jól látható az acélcsőrács-szerkezetű törzs és a vastag profilú szárnybordázat (Winkler Aero Archív)

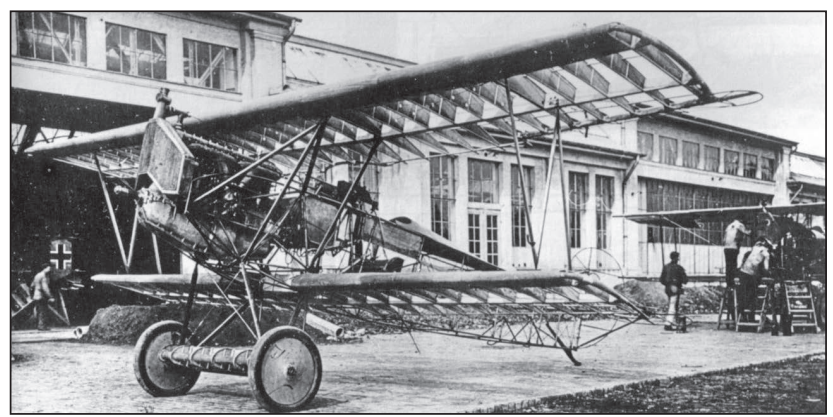




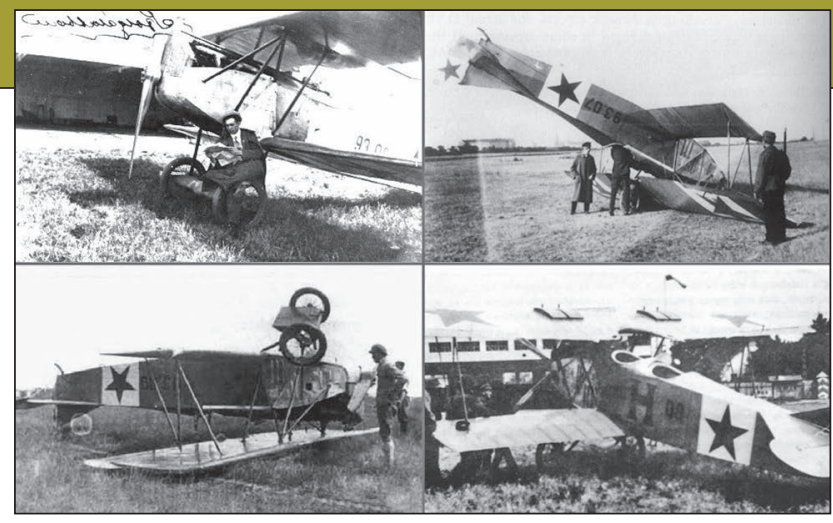

6. ábra. Különböző vörös csillagos Fokkerek: a 93.03 (?) motorburkoló lemez nélkül, a 93.07 és a 93.09 átbukva, és a négyágú légcsavarral felszerelt H.08-as, felső szárnyán a négy áramvonalas kiegészítő benzintartállyal (Fotó: airwar.ru)

repülőgépgyár, ahol némileg áttervezték a repülőt, némely alkatrész nem volt csereszabados egymással.) A motorszámok alapján azonban nem volt köztük a magassági BMW IIla motoros D.VII(F) változat. A vadászrepülőgépekkel felszerelt 1. repülőosztálynak 1919. február 3-án utaltak ki 3 gépet, a 3247/18 (?), 4072/18, 5146/18 sárkányszámúakat [11]. Ezekről nem maradt fenn több adat, huzamosabb ideig nem használhatták a gépeket. Az alakulat ekkoriban föleg kiképzőrepüléseket végzett. További két szétszerelt D.VII-es került román kézre április 23-án Debrecenben, amiket korábban a Székely Hadosztály (7.) repülőszázada hagyott hátra. Ebből az egyik, a 76.06 számú júniusban javítás alatt ált a román „Raktár” századnál, júliusban pedig már a B.2 század jelentett egy működőképes Fokker D.VII-est. Mindenesetre a román forrásokból is kitűnik, hogy a zsákmányolt repülőgépek motorjai rendkívül elhasználtak voltak.

\section{MÁTYÁSFÖLDI FOKKEREK}

A fénykorában 1100 főt foglalkoztató mátyásföldi Magyar Általános Gépgyár (MÁG) 1915-ben lett a monarchia 9. számú repülőgépgyára úgy, hogy előző évben már repülőmotort is gyártott a Váci úti üzemében $[6,12]$. A repülőüzemében Berg és Fokker licencek alapján gyártottak repülőgépeket. A motorgyártó részlegében kizárólag Daimler típusú motorokat állítottak elő, amit a saját, illetve az aszódi Lloyd gyártású repülőkbe építettek be. A cégnél részvényes és igazgatósági tag is volt Anthony Fokker. A MÁGnak a szerződés szerint $150 \mathrm{db}$ D.VII-est 1918 decembere és 1919 márciusa között kellett leszállítania [6]. 1918. október 11-én repült először az első mintapéldány, a 93.01 számú (3-as jelölte a MÁG Fokker D.VII-es szériát), és a hó végén már $35 \mathrm{db}$ repülőgép volt végszerelési stádiumban. Bár az acélcsőrács-szerkezetű törzs építése lassította a

7. ábra. Archív fotó a Mátyásföldön álló schwerini D.VII-esről. A gép függőleges vezérsíkján alig észrevehető a vörös csillag jelzés. A gépeket a gyár kései, 4 színű (alul más árnyalatú) Fokker álcázó festésével szállították a hadseregnek

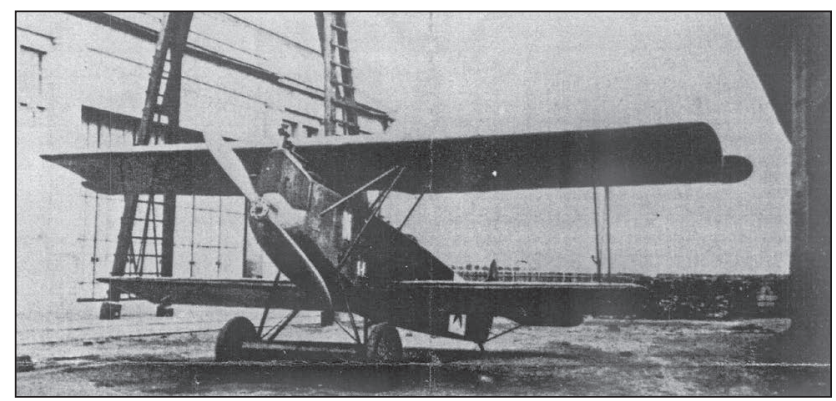

1. táblázat. A V.22-es jelü Fokker D.VII egymotoros, kétfedeles, együléses vadászrepülögép fontosabb adatai [12]

\begin{tabular}{|l|c|}
\hline Fesztávolság - felső szárny & $8,90 \mathrm{~m}$ \\
\hline Fesztávolság - alsó szárny & $7,00 \mathrm{~m}$ \\
\hline $\begin{array}{l}\text { Szárnyfelület } \\
\text { (felső, alsó, keréktengely) }\end{array}$ & $13,50,6,95,1,20 \mathrm{~m}^{2}$ \\
\hline Hosszúság & $6,94 \mathrm{~m}$ \\
\hline Magasság & $2,81 \mathrm{~m}$ \\
\hline $\begin{array}{l}\text { A repülőgép üres (nettó) } \\
\text { tömege }\end{array}$ & $689 \mathrm{~kg}$ \\
\hline $\begin{array}{l}\text { A repülőgép } \\
\text { felszállótömege }\end{array}$ & $908 \mathrm{~kg}$ \\
\hline Felületi terhelés & $45 \mathrm{~kg} / \mathrm{m}^{2}$ \\
\hline Maximális sebesség & $196 \mathrm{~km} / \mathrm{h}$ \\
\hline $\begin{array}{l}\text { Emelkedés idótartama } \\
3000 \text { m magasságra }\end{array}$ & $9 \mathrm{perc}$ \\
\hline Csúcsmagasság & $7500 \mathrm{~m}$ \\
\hline Hatótávolság & $600 \mathrm{~km}$ \\
\hline
\end{tabular}

munkát (lásd a megfelelő hegesztők beszerzésre), azonban a „kincsesláda” törzsforma egyszerűsítette azt [17]. A gyártást budapesti telephelyű beszállítók is segítették, köztük a jellegzetes motorhűtőt készítő Automobil Hűtőgyár, vagy a jó hatásfokú, korszerü légcsavarokat szállító Asbóth-féle Első Magyar Légcsavargyár [6, 12, 16]. A szériagyártású repülőgép a MÁG kimutatása alapján 190000 koronába került, motor nélkül azonban csak 100 000-be. Egypár M16-os Schwarzlose repülőgéppuska további 40 000-be, de a legjobban használódó légcsavarból is egy ládányi 7500 koronába került [24]. A csőszerkezet és a vastag szárnyak ellenére nem volt drágább, mint a 92 szériás Aviatik D.I Berg vadászgép. A MÁG D.VII-esbe 225 LE-s Austro-Daimler motort épített be, amit a MÁG repülömotor-üzemében licenc alapján készítettek [6, 10, 12]. A rendelkezésre álló fotókon feltűnő, hogy a bevetésre került repülőkön hiányoznak a különböző motortakaró lemezek. Ez hűtési problémákra utalhat, hiszen a szintén ugyanezt a motort használó, 348-as szériaszámú aszódi D.I Berg-ek felső szárnyára már nagy motorhűtőt szereltek [12]. A gyártás alatt lévők között volt a D.VII-es kétüléses fegyveres változata, a MÁG Fokker C.I-es. A 196-os és 197-es sorozatszámmal készült 10 darab gép a H.01-H.10 jelzést kapta [6, 24]. A C.I-esek nagyobb fesztávú felső szárnyába további négy áramvonalas benzintartályt is beépítettek. A háború vége miatt a gyártást felfüggesztették, de az igazi csapást a kormánybiztosság november 8-ai rendelete okozta, ami elrendelte a repülőgépgyárak $75 \%$-os létszámcsökkentését és a termelés $25 \%$-ra történő mérséklését $[6,12,16,19]$.

1918. november elején - rögtön a fegyverszünet után - a MÁG mátyásföldi gyári repülőterén, a gyárban fellelt hat „papírszárnyú” D.I Berg vadászgéppel megalakult az l. Légi rendőrségi osztály. November 16-ig összesen nyolc 1-3 gépes bevetést végeztek Budapest 100 km-es sugarában karhatalmi és röpcédulaszórás feladattal. A bevetésükön a 6-ból $3 \mathrm{db}$ Berg-gép is kényszerleszállást hajtott végre, ezek pótlására kapták meg az aszódi gyárban lévő kétüléses Phönix C.I-es mintagépet. November 14-én a MÁG 
állományából kiutaltak 7 db Fokker D.Vl-os géppuska nélküli vadászgépet, amelyek szintén motorbeszerelésre érkeztek Németországból. Ugyanekkor felkínálták a működőképes 93.01-est és még motor nélkül álló $6 \mathrm{db}$ német Fokker D.VIl-est is [10].

1919. január 4-én átszervezték a légierőt. A Magyar Repülő Csapatok keretén belül a korábbi repülőosztályok átcsoportosításával és összevonásával, egységes számozással 8 harci repülőosztályt állítottak fel: 1. Mátyásföld, 2. Albertfalva, 3. Győr, 4. Kaposvár, 5. Szeged, 6. Arad, 7. Debrecen, 8. Rákos $[12,20]$. A kiképző repüléseket végző mátyásföldi alakulat az új szervezeti rendben az egyetlen vadászalakulatként szerepelt. 1919. február 3-án az osztálynak kiutalt repülők között volt a három zsákmányolt német, a MÁG 93.01-es és a 3861, 3863-3867-ig számú D.VII-es. Ezen a napon csak a 93.01-es és a Phönix volt bevethető, például a D.VI-osok a ricinusolaj hiánya miatt voltak földhöz szegezve [10].

Márciusban a 93.01-es mellett már bevethető volt mind a 6 német $\mathrm{D}$.VII-es [5]. A Tanácsköztársaság kikiáltása után utasították a gyárakat a termelés beindítására, és a már kész gépeket átadták az alakulatoknak. A világháborús tapasztalatok alapján ugyanis úgy számoltak, hogy egy repülőszázad 3 hónap alatt teljesen elveszíti repülőparkját, és ezt folyamatosan pótolni kell. A felderítő-századoknál 8 $\mathrm{db}$, a vadászszázadnál $12 \mathrm{db}$ repülőt terveztek. Az első körben többek között 10 aszódi gyártású „erős” D.I Berget osztottak szét a századok között $[6,10,12]$. A jelentkező nyersanyaghiány enyhítésére egy különleges alakulatot állítottak fel [12], amelynek tagjai illegális úton csempészték be a Wiener Neustadt-i repülőgépanyag-szertárból szerzett különleges vásznat, lakkot, gumiköpenyt, műszereket és repülőgéppuskákat. Nyár közepére a gyártás úgy felfutott, hogy már a cinkotai szertárban kellett tárolni az új repülőgépeket. Ennek egyik oka feltehetően az volt, hogy a Károlyi-kormány által elrendelt leépítések után, a repülőgyári munkások között a kommunisták rendkívül népszerűek lettek (politikai megmozdulásaikon rendszeresen részt vettek), és a párt folyamatos rendelésekkel igyekezett megtartani jelentős tömegbázisát az idővel államosított gyárakban $[4,18,24]$.

\section{(Folytatjuk)}

\section{FoRRÁSOK}

[1] Batchelor, John; Lowe, Malcolm V. A repülés enciklopédiája 1848-1939, Budapest: Gabo. 2005;

[2] Boksay Antal. A felhők katonái. Budapest: Aquila, 2001;

[3] Bonhardt Attila, Sárhidai Gyula, Winkler László: A Magyar Királyi Honvédség fegyverzete. Budapest: Zrínyi, 1992;

[4] Brannon, Edgar. Fokker D. VII in action. Squadron/ SignalCarollton, 1997;

[5] Czirók Zoltán. „Az első légi háború Magyarország felett - 1919." Hadtörténeti Közlemények 124. évf. 2. sz. (2011). 335-364 p. http://epa.oszk. hu/00000/00018/00053/pdf/EPA00018 hadtortenelmi_2011_2 335-364.pdf;

[6] Czirók Zoltán. „A magyar repülőcsapatok 1918 1919. évi történetéhez" Hadtörténelmi Közlemények, 122. évf. 3. sz (2009): 603-634. p. http://epa.oszk. hu/00000/00018/00060/pdf/EPA00018_ hadtortenelmi_2009 03.pdf;

[7] Czirók Zoltán. „Repülőszázadok Ongán - 1919.” 1. rész Ongai Kékdaru. 2009. november 10-11. o.
2. rész Ongai Kékdaru. 2009. december 11. o.

3. rész Ongai Kékdaru. 2010. január 10-11. o.

4. rész Ongai Kékdaru. 2010. február 10-11. o. http://www.okeonga.hu/documents/om/repsz.pdf;

[8] Czirók Zoltán. „Hadirepülők Rákoson (1918-1919).” Magyar Repüléstörténeti Társaság évkönyve, 2011. 33-48. o. http://iwk.hu/_userfiles_aviatika/033_048\%20CzirokZ̄oltan\%20-\%20 Hadirepulok\%20Rakoson.pdf;

[9] Czirók Zoltán. „Az „E-akció”, avagy kísérlet a magyar katonai aviatika megmentésére - 1920-1921." Hadtörténelmi Közlemények 126. évf. 3. sz. (2013): 791-801. p. http://epa.oszk.hu/00000/00018/00028/ pdf/EPA00018_hadtortenelmi_2013_3_791-804.pdf;

[10] Czirók Zoltán. Katonai repülők Mátyásföldön (1918-1919). Magyar Repüléstörténeti Társaság évkönyve, 2014. 54-70. p.;

[11] Czirók Zoltán. „Német repülőgépek a Balkánról.” A Repüléstörténeti Konferencia Közleményei, 2009. 168-172. o. http://iwk.hu/_userfiles_/aviatika/168\%20CzirokZoltan\%20NemetRepulogepek.pdf;

[12] Csanádi Norbert, Nagyváradi Sándor, Winkler László. A magyar repülés története. Budapest: Müszaki, 1977;

[13] Gáspár Ferenc, Mann Miklós. Danuvia 50 éve. Budapest: Danuvia, 1971;

[14] Gerencsér Miklós. Az északi arcvonal. Budapest: Szépirodalmi, 1989;

[15] Gunston, Bill. Korszerű harci repülőgépek fegyverzete. Budapest: Zrínyi, 1995;

[16] Horváth Lajos. Katonák a Rákos és a Galga mentén. Gödöllő: Műv. Kp., 1989;

[17] Knight, Brian. Fokker D.VII Anthology I., II., III. Albatros Publishing, 2002;

[18] Liptai Ervin. Vöröskatonák, elöre! Budapest: Zrínyi, 1979;

[19] Magyarország az Első Világháborúban. Lexikon. Budapest: Petit Real,1999;

[20] Nagyváradi Sándor, M.Szabó Miklós, Winkler László Fejezetek a magyar katonai repülés történetéböl, Budapest: Műszaki, 1986;

[21] Pataky Iván, Rozsos László, Sárhidai Gyula. Légi háború Magyarország felett I-II. Budapest: Zrínyi, 1992;

[22] Jackson, Robert. Air War Flanders-1918. Airlife Publising, 1998;

[23] Winkler László. „A magyar repülőtechnika 50 éve (1916-1966)" Technikatörténeti szemle 4. Bp.: 1967;

[24] Aero História, Közlekedési Múz. 1989/jún., 1989/ dec., 1990/dec., 1992/okt.;

[25] Air Enthusiast, No. 60, 61, 62;

[26] Haditechnika 27/2. sz. (1993), 30/2. sz. 10-15. o., 30/4. sz. 77-79. o. (1996), 43/4-5. sz., 15-19. o, 14-18. o. (2009);

[27] Magyar Szárnyak 1939/05

[28] aviatika.iwk.hu. „Magyar repülőcsapatok 19181921". aviatika. Elérés 2020. március 24. https:// aviatika.iwk.hu/magyar-repulocsapatok-1918-1921/;

[29] „Fokker D.VII - Drawings”. Elérés 2020. március 24. https://www.fokkerdvii.nl/;

[30] Dokumentum gyüjtemény: A magyar Vörös Hadsereg 1919-ben. Budapest: Kossuth, 1959;

[31] "Welcome to The Aerodrome - Aces and Aircraft of World War I". Elérés 2020. március 24. http://www. theaerodrome.com/index.php;

[32] „WWI Aces and Airplanes - New Weapons of the Great War". Elérés 2020. március 24. http:// acepilots.com/wwi/. 